\title{
Primary Investigation in the Completeness Evaluation Model of Accounting System in Agricultural Enterprises
}

\author{
Dan Feng \& Gang Fu(Corresponding author) \\ College of Economic and Management, Sichuan Agricultural University \\ Wenjiang 611130, Chengdu, China
}

Received: February 20, 2012

Accepted: March 30, 2012

Published: May 15, 2012

doi:10.5430/afr.v1n1p230

URL: http://dx.doi.org/10.5430/afr.v1n1p230

\begin{abstract}
The basic content of accounting system in agricultural enterprises includes the five aspects of financial accounting system, accounting organization system, accounting supervision system, accounting management system and internal control system. In order to evaluate completeness of accounting system in agricultural enterprises in a comprehensive and quantitative way, this article sets up the evaluation model of completeness of accounting system in agricultural enterprises with the aim of discovering some weak aspects in the accounting system in agricultural enterprises, improving the accounting system in agricultural enterprises and making the accounting system in agricultural enterprises more scientific, rational, effective and maneuverable.
\end{abstract}

Keywords: Agricultural enterprises, Accounting system, Evaluation model

\section{Introduction}

The major function of accounting is accounting and supervision on economic activities. The accounting system is generated in order to standardize the accounting job and realize the function of accounting and supervision of accounting. The accounting system is the important evidence and rule to standardize accounting information and further ensure the quality of accounting job and it helps to offer more systematic, comprehensive and stronger decision-making accounting information for all information demanders. The accounting system is defined in the dictionary of accounting as "accounting system is a unified rule of accounting job, including norms, methods, procedures and regulations, and is a criterion that the accounting job has to follow." The major content of accounting includes general rules of accounting job, accounting subjects and introductions, accounting items handling procedures, cost calculation rules, accounting report form and compilation introduction and accounting file management rules, etc. The accounting system in its broad sense also includes setting of accounting agencies, methods of physical inventory, methods of accounting analysis, compilation of financial situation statement, examination and approval procedure of accounting report, internal accounting control and application of electronic computer in accounting, etc. As a necessary aspect in completeness of accounting system, completeness evaluation of accounting system concerns about whether the accounting system of the enterprises is scientific and reasonable and whether it is able to realize its accounting functions. Therefore, its important effect should not be ignored.

Agricultural enterprises refer to enterprises that are characterized by operation of farm production and livestock breeding. According to different business operation scopes, agricultural enterprises can be classified into several types, such as, all sorts of professional and comprehensive enterprises which mainly produce agricultural products, agricultural, industrial and commercial associations which combine agricultural products production, processing, transportation and sales, and other service enterprises that directly offer agricultural production service, etc. Agriculture is a relatively special industry and agricultural production activities are activities in which natural reproduction and economic reproduction are combined together. On one hand, agricultural production activities are closely related with the natural conditions and are vulnerable to the natural disasters. On the other hand, agricultural production periodicity is long and the productive seasonality is obvious. In addition, the subjects of agricultural production and operation are mostly farmers with low cultural quality. All these factors enable agricultural enterprises to have a lot of problems in terms of accounting and the phenomenon of inauthentic accounting information is serious. Thus, it is extremely urgent to strengthen and improve accounting system construction in agricultural enterprises. At present, most studies by the domestic scholars on accounting system focus on establishment of the accounting system, existing problems and solutions, while there have seldom had any study on evaluation on the accounting system, which, to a large extent, restrains further study on the 
theory of accounting system and further development of accounting system practice, let alone studies on evaluation of accounting system in agricultural enterprises. Based on this situation, this article attempts to discuss the model of completeness evaluation on accounting system in agricultural enterprises.

In 1965, US cybernetics expert Professor L.A.Zaden published a thesis titled "Fuzzy Sets" in the magazine of "Information and Control", which symbolized birth of fuzzy mathematics. Fuzzy mathematics offers a reliable quantitative analysis method for the property of those fuzzy objects and also opens a new train of thought for evaluation of completeness of accounting system. In light of fuzziness in evaluation content of accounting system in agricultural enterprises, this article attempts to employ fuzzy comprehensive evaluation method to set up the comprehensive completeness evaluation model of accounting system in agricultural enterprises. This method is mainly quantitative evaluation and is assisted by qualitative evaluation. With organic combination of the two, the fuzziness phenomenon is appropriately accurate and the qualitative analysis is quantified, which improves objectivity, scientificalness and maneuverability of completeness evaluation of accounting system in agricultural enterprises, which, to some extent, avoids excessive subjectivity in unique employment of qualitative evaluation method. From the perspective of micro enterprises, this article has a train of thought of frame style evaluation and employs fuzzy comprehensive evaluation method to set up the model of completeness evaluation of accounting system in agricultural enterprises, with the aim of evaluating whether the accounting system in agricultural enterprises is complete and how much the completeness is so as to discover some deficiencies existing in accounting system in agricultural enterprises, improve the accounting system in agricultural enterprises and make accounting system in agricultural enterprises more scientific, reasonable, effective and maneuverable.

\section{The basic framework of accounting system in agricultural enterprises}

According to the connotation of accounting system, professional features of agricultural enterprises and new accounting standards system for business enterprises (the new accounting standards system for business enterprises includes basic standard, specific standard and accounting standard application guidance and explanation) and other accounting rules, this article holds the viewpoint that the basic content of accounting system of agricultural enterprises in its broad sense includes the five aspects of accounting system, accounting organization system, accounting supervision system, accounting management system and internal control system.

2.1 System of accounting in agricultural enterprises includes accounting information confirmation, collection, recording and specific requirements and standards in terms of application, which mainly includes design of accounting document, selection and design of accounting subjects, book and accounting report, selection of accounting form and financial treatment procedure system, etc. Scientific and perfect accounting system is not only the need to perform the functions of accounting in reflecting and supervising economic activities of agricultural enterprises, but is also the need to offer authentic and complete information of agricultural enterprises for all information users, the primary and most important system in the five systems of accounting system. Thus, agricultural enterprises should carry out complete accounting system according to the industrial features of agriculture and new accounting standards system for business enterprises. Accounting subjects and the usage introduction require that the new accounting standards system for business enterprises stipulate the title, code number, accounting content and usage methods of the total classification items required by agricultural enterprises. According to the characteristics of agricultural biological assets, "Biological Assets --- NO.5 of Accounting Standards for Business Enterprises" specially specifies confirmation, initial calculation and subsequent calculation of biological assets for agricultural enterprises and accounting methods of acquisition and disposal. The accounting document requires to make stipulations on the format, order, usage, transfer procedure, filling requirement and storage method of all sorts of documents. Stipulations on the articulation relations between the categories and format of the accounting books and all sorts of accounting books require to set up a strict and perfect accounting book system and usage and storage system. Stipulations on the accounting reports require to clearly define the category, format, content, usage, compilation method and submission object of internal accounting reports, connect together relevant indexes of internal reports and externally submitted reports and form a complete accounting report system. As for the system about financial treatment procedure, it is required that the enterprises make a definite stipulation on what kind of financial treatment procedure to use and the document and accounting books required thereby, set up accounting index system for the enterprises, define accounting method and ensure that the accounting of enterprises is operated on the feeble-minded basis of colleges and universities.

2.2 Accounting organization system includes setting of corporate accounting agency, allocation of accounting personnel and job standard, handing-over procedure of accounting job and archives administration, etc. Complete accounting organization system helps to ensure high efficiency and low consumption of energy in accounting, avoids the phenomena of overstaff and waste of human power within the accounting agencies and the situations of suppression on 
people due to over burden and uneven labor and rest, strengthens the sense of responsibility and sense of mission among accountants and ensures orderly and scientific ongoing of accounting. The enterprises are supposed to set up scientific and rational accounting agencies according to requirements of the accounting business and for those enterprises that are not qualified to set up independent accounting agencies, they ought to equip professional accountants and principals for accounting agencies in relevant institutes. It is necessary to rationally stipulate internal organization agencies, classify job positions, properly equip the accounting personnel quantity and technical titles for all job positions, carry out limits of authority for all job positions and the coordination methods between different job positions. Handing over of accounting archive management and accounting work requires to make stipulations on storage, reading and destroying of accounting archives and how to hand over accounting work to ensure completeness and security of accounting archives and orderliness of accounting handing over.

2.3 Accounting supervision system of agricultural enterprises includes evidence for accounting supervision, accounting supervision methods, subject of accounting supervision and the mode of accounting supervision, etc. Accounting supervision includes internal supervision and external supervision. Strengthening accounting supervision on agricultural enterprises helps for successful development of accounting job, offers authentic and complete accounting information and gives full play to the management function of accounting, etc. Accounting agencies and accountants in the enterprises are supposed to make accounting supervision on economic activities of enterprises. The content of accounting supervision mainly includes whether the auditing enterprises are able to follow relevant legal regulations of accounting, whether the accounting information is authentic and complete and also the implementation condition of budgeting, financial plan, economic plan and business plan of the enterprises.

2.4 Accounting management system of agricultural enterprises includes regulations on post responsibility and scope of official duty for accounting of business enterprises, regulations on capital use, cashier and application for reimbursement, regulations on basic procedure in internal and external financial relationship in enterprises, auditing system, original record management system, physical inventory system, quota management system, cost accounting system and financial accounting analysis system, etc. Accounting management system helps to strengthen the management function of accounting, improve the management level of accounting and ensure quality of accounting work. Agricultural enterprises ought to take an overall consideration of the agricultural production features and internal management requirement and set up and improve corresponding internal accounting management system. Agricultural enterprises are supposed to set up an auditing system, which includes the organization form and specific division of labor of auditing work, obligations and limits of authority of auditing work, auditing accounting document and re-auditing accounting books and methods of accounting reports. Content of original recording management system includes content and filling method of original recording, format of original recording, auditing of original recording, responsibility of those who fill in the original recording, signature of original recording and transfer and collection requirement of original recording. Content of quota management system includes scope of quota management, proof, procedure and method of carrying out and revising quota, implementation of quota and quota assessment and rewarding and punishment methods, etc. Content of physical inventory system includes scope of physical inventory, organization of physical inventory, time limit and method of physical inventory, handling method for problems discovered in physical inventory and rewarding and punishment method for physical inventory personnel. The major content of examination and approval system of financial revenue and expenses includes assessing personnel for examination and approval of financial revenue and expenses and limits of examination and approval authority, procedure for examination and approval system of financial revenue and expenses, and responsibility of assessing personnel for examination and approval of financial revenue and expenses, etc. Content of cost calculation system includes the objects for cost calculation, method and procedure for cost accounting and cost analysis, etc. Content of financial accounting analysis system includes the major content of financial accounting analysis, basic requirement and organization procedure for financial accounting analysis, specific methods for financial accounting method and compilation requirement for report of financial accounting analysis, etc.

2.5 Internal control system of agricultural enterprises includes monetary capital control, external investment control, physical assets control, procurement and payment control, financing control, expense control and internal control in sales of products. According to definition by specific standards of internal control and audit risk in China on internal control, "it refers to policies, measures and procedures carried out and implemented by the units to ensure effective proceeding of business activities, protect property safety and completeness, prevent, discover and correct mistakes and malpractices and ensure authenticity, legality and completeness of accounting materials". Thus, it can be seen that, the role of internal control system is to protect implementation of accounting system, prevent mistakes and eradicate malpractices, protect safety and completeness of agricultural property, ensure authenticity and completeness of accounting information, strengthen the system of post responsibility and improve accounting efficiency. Agricultural enterprises ought to set up monetary capital post responsibility system, make clear obligations and limits of authority for 
relevant sections and positions and ensure mutual separation, restraint and supervision of incompatible positions that handle monetary capital business. In addition, agricultural enterprises should also set up the authorization approval system for monetary capital, clearly define the examination and approval personnel and auditing personnel for monetary capital business, specify the authorization and approval mode, limits of authority, procedure, obligation and relevant control measures of examination and approval personnel for monetary capital business, and specify the obligation scope and work requirements of handling personnel in handling monetary capital business. Material object assets control mainly finds out critical control points from obtaining, storing, claiming, sending out, inventory making and processing of material object assets, adopt mutual separation of authorization approval, accounting record and material object storage and take a series of controlling method, such as, non-material object storage personnel have no right to claim for goods, etc., to prevent material object assets from being stolen, destroyed or lost. Procurement and payment control mainly adopts the mode of separation of powers control to let different relevant personnel finish the different jobs of planning, procuring, acceptance inspecting, auditing, paying and keeping accountings of procurement business who respectively take their own responsibility so as to separate all different jobs, ensure quantity and quality of the goods procured, and prevent the phenomenon that the procurement personnel take commission on sales personally. There are quite a lot of internal control modes, including mutual separation and control of incompatible positions, authorization approval control, accounting system control, budget control, property preservation control, risk control and internal report control, etc. Different economic businesses have different control modes and agricultural enterprises ought to select appropriate control modes according to their own characteristics. Agricultural enterprises are supposed to set up internal check system, which includes the principle of internal check system, organization and division of labor, obligation and restraint conditions of the cashier position and obligations and limits of authority of relevant positions.

\section{Establishment of completeness evaluation in accounting system in agricultural enterprises}

Completeness of evaluation on accounting system in agricultural enterprises specifically includes legality, compliance, rationality, systematicalness, scientificalness, adaptability, completeness and maneuverability, etc., and the evaluation results offer proof for discovering deficiency of accounting system, which is convenient for enterprises to propose opinions and suggestions for improvement pertinently. As for evaluation on accounting system, most existing studies focus on the qualitative method. However, the qualitative evaluation is too strong in subjectivity, so it might affect scientificalness of the evaluation results. Thus, this article attempts to adopt the method of combination of qualitative and quantitative research and sets up fuzziness comprehensive evaluation model for completeness of accounting system in agricultural enterprises, with the expectation of obtaining a more scientific evaluation result. The reason why this article adopts fuzziness comprehensive evaluation model is that evaluation on completeness of accounting system can usually only be described in fuzzy language, while fuzzy mathematics offers a reliable quantitative analysis method for judging attributes of fuzzy objects.

\subsection{Establishment of index system}

According to the above content framework of accounting system in agricultural enterprises and the connotation of completeness in accounting system, this article sets up the index system for evaluation on completeness of accounting system in agricultural enterprises from the five aspects of accounting system in agricultural enterprises. According to the selection principle of combination of qualitative and quantitative methods and combination of importance and maneuverability and the internal requirement of reflecting "scientificalness and effectiveness", selection of indexes reflects the financial indexes and non-financial indexes of multiple features of legality, compliance, rationality, systematicalness, scientificalness, adaptability and maneuverability with the expectation of reflecting completeness level of accounting system in agricultural enterprises in an objective and justified way. Please see Table 1 for specific accounting indexes.

$<$ Insert Table 1 here $>$

\subsection{Establishment of factor sets}

Establishment of factor sets set up the following evaluation factor sets in accordance with the indexes for evaluation on completeness of accounting system in agricultural enterprises as listed in Table 1:

$\mathrm{U}=\left\{\mathrm{U}_{1}, \mathrm{U}_{2}, \mathrm{U}_{3}, \mathrm{U}_{4}, \mathrm{U}_{5}\right\}$

Besides, $\mathrm{U}_{\mathrm{i}}(\mathrm{i}=1,2,3,4,5)$ respectively stand for a class one index, namely, the five aspects in the content of accounting system in agricultural enterprises. Where, $\mathrm{U}_{1}=\left\{\mathrm{U}_{11}, \mathrm{U}_{12}, \mathrm{U}_{13}, \mathrm{U}_{14}, \mathrm{U}_{15}, \mathrm{U}_{16}\right\}$

$\mathrm{U}_{2}=\left\{\mathrm{U}_{21}, \mathrm{U}_{22}, \mathrm{U}_{23}, \mathrm{U}_{24}, \mathrm{U}_{25}\right\} ; \mathrm{U}_{3}=\left\{\mathrm{U}_{31}, \mathrm{U}_{32}, \mathrm{U}_{33}, \mathrm{U}_{34}, \mathrm{U}_{35}, \mathrm{U}_{36}, \mathrm{U}_{37}\right\}$

$\mathrm{U}_{4}=\left\{\mathrm{U}_{41}, \mathrm{U}_{42}, \mathrm{U}_{43}, \mathrm{U}_{44}, \mathrm{U}_{45}, \mathrm{U}_{46}\right\} ; \mathrm{U}_{5}=\left\{\mathrm{U}_{51}, \mathrm{U}_{52}, \mathrm{U}_{53}, \mathrm{U}_{54}, \mathrm{U}_{55}, \mathrm{U}_{56}, \mathrm{U}_{57}, \mathrm{U}_{58}, \mathrm{U}_{59}\right\}$ 


\subsection{Establishment of evaluation sets}

In order to evaluate the degree of advantages and disadvantages of all indexes, it is also necessary to set up an evaluation sets. This model adopts the evaluation mode of different classes from a higher class to a lower class of $\mathrm{V}=\left(\mathrm{v}_{1}, \mathrm{v}_{2}, \mathrm{~V}_{3}, \mathrm{v}_{4}\right)$. Four classes of "yes", "almost yes", "not much yes" and "no" are classified in the process of evaluation. Referring to the previous research achievements and relevant data, we give an assignment of respectively "1.0, $0.7,0.4,0.1$ " to the four classes.

\subsection{Construction of fuzziness evaluation matrix}

As for the fuzziness relationship from $\mathrm{U}$ to $\mathrm{V}$, we can represent it with the fuzziness evaluation matrix $\mathrm{R}$ :

$$
\begin{gathered}
R_{1}=\left[\begin{array}{llll}
r_{11} & r_{12} & r_{13} & r_{14} \\
r_{21} & r_{22} & r_{23} & r_{24} \\
& \ldots & & \\
r_{61} & r_{62} & r_{63} & r_{64}
\end{array}\right] \quad R_{2}=\left[\begin{array}{llll}
r_{11} & r_{12} & r_{13} & r_{14} \\
r_{21} & r_{22} & r_{23} & r_{24} \\
& \ldots & & \\
r_{51} & r_{52} & r_{53} & r_{54}
\end{array}\right] \quad R_{3}=\left[\begin{array}{llll}
r_{11} & r_{12} & r_{13} & r_{14} \\
r_{21} & r_{22} & r_{23} & r_{24} \\
\ldots & & \\
r_{71} & r_{72} & r_{73} & r_{74}
\end{array}\right] \\
R_{4}=\left[\begin{array}{ccccc}
r_{11} & r_{12} & r_{13} & r_{14} \\
r_{21} & r_{22} & r_{23} & r_{24} \\
& \ldots & &
\end{array}\right] \quad R_{5}=\left[\begin{array}{lllll}
r_{11} & r_{12} & r_{13} & r_{14} \\
r_{21} & r_{22} & r_{23} & r_{24} \\
& \ldots & & \\
r_{61} & r_{62} & r_{63} & r_{64}
\end{array}\right]
\end{gathered}
$$

Generally speaking, subjective qualitative indexes all have fuzziness to a certain extent. We mainly adopt self-evaluation method for enterprises as for the fuzziness evaluation method of this sort of indexes and adopt the method of sending out questionnaires to internal employees of agricultural enterprises and collecting scores to confirm that the degree of membership of a certain evaluation object $\mathrm{U}_{11}$ to $\mathrm{V}_{\mathrm{j}}(\mathrm{j}=1,2,3,4)$ adopts the hierarchy proportion method. For details, please see Table 2 .

$<$ Insert Table 2 here $>$

\subsection{To determine the weight}

In determination of the weight, this article employs the method principle of Analytic Hierarchy Process. Firstly, this article constructs the multiple comparison determination matrix of each level of elements to the importance of the upper level of dominant elements, namely, construction of inverse matrix A. Usually, opinions of several experts are concentrated. It is required that, (1) all experts should independently make the paired comparison and the assignment of the kth expert to $x_{i} / x_{j}$ is presented as:

$a_{i j k} i, j=1,2, \ldots . . n, K=1,2, \ldots . ., m$

(2) Geometric mean is calculated as $a_{i j}=\sqrt[m]{\prod_{k=1}^{m} a_{i j k}}$. After the inverse matrix A is constructed, we then use the

linear algebraic method to work out the maximum eigenvalue $\lambda_{\max }$ and the corresponding eigenvector $\mathrm{W}$ so as to educe the weight of these elements that is allocated from the upper dominant elements from this determination matrix. The weight sets is represented as $W=\left\{W_{1}, W_{2}, \cdots, W_{m}\right\}$, where $\mathrm{m}$ is the index sum.

\subsection{Composition arithmetic}

By means of the composition arithmetic of fuzziness matrix, we get the comprehensive evaluation model $Y_{i}=W_{i} R_{i}$.

$Y_{i}$ constitutes the row vector of the fuzzy relation matrix $\mathrm{R}$ that is a class one comprehensive index. Then, we get

$Y=\left[\begin{array}{l}Y_{1} \\ Y_{2} \\ Y_{3} \\ Y_{4} \\ Y_{5}\end{array}\right]$ 
According to the weight vector $W$ that is a class one comprehensive index and the fuzziness evaluation vector $Y$ that is an item evaluated, we work out and generate the fuzziness evaluation result vector as follows:

$B=W Y=\left(b_{1}, b_{2}, b_{3}, b_{4}\right)$

Where, $b_{m}$ stands for the degree of membership of the evaluated objects to the comment sets $V$ from a general perspective.

We respectively make an inner product to the fuzziness evaluation result vector $B$ and the fraction vector$\{1.0,0.7,0.4,0.1\}$ represented by the evaluation sets factors and then quantify it as the final comprehensive scoring of completeness of accounting system in agricultural enterprises.

\section{Conclusion}

Agricultural enterprises are a category of particular enterprises in that both the objects of agricultural production activities and agricultural production means are animate biological assets and a large majority of agricultural production and operation subjects are farmers with low cultural quality. These features of agricultural enterprises make the accounting system in agricultural enterprises have a lot of problems and fail to offer authentic, legal and complete accounting information. Thus, it is already quite urgent to discover and resolve existing problems in accounting system in agricultural enterprises. However, how to discover straightly and effectively existing problems in accounting system in agricultural enterprises? The tradition method is to adopt the qualitative analysis method. Nonetheless, according to the author, on one hand, the traditional qualitative analysis is not strong in systematicalness and completeness. On the other hand, it is also relatively weak in terms of intuitiveness and objectivity. Thus, on the basis of the tradition method, this article combines the qualitative and quantitative method and sets up the fuzziness comprehensive evaluation method for completeness of accounting system in agricultural enterprises. Appearance of fuzzy mathematics offers a possible method for evaluation on the specious and fuzzy objects. Evaluation on completeness of accounting system can usually only be described in fuzzy language and it is difficult to deal with it with an accurate mathematical method. Thus, this article adopts the fuzziness comprehensive evaluation method and makes the fuzziness phenomenon more accurate in appropriateness and more quantified in qualitative analysis appropriateness so as to realize the more objective and accurate effect than pure usage of qualitative analysis.

Ultimate determination of the weight of completeness of accounting system in agricultural enterprises fully indicates which accounting system content is relatively important for agricultural enterprises and which accounting system content is secondly important for agricultural enterprises. Agricultural enterprises ought to pay special attention to improvement on the accounting system content that is relatively important. Ultimate comprehensive scoring of evaluation on completeness of accounting system in agricultural enterprises reflects whether the accounting system of the agricultural enterprises is complete and the degree of completeness. From the degree of membership of all indexes and the single item scoring result of class one indexes, we can see which accounting system is still weak and still has deficiency. Agricultural enterprises should put forward policies to improve accounting system of agricultural enterprises in light of the deficiency of the accounting system and make the accounting system o agricultural enterprises more legal, complete, scientific and rational.

\section{References}

An, Fugui \& Liu, Ting. (2003). Inquiry into the Agicultural Accounting System. Chinese Agricultural Accounting, 11.

Chen, Jianhong. (2011). Establishment of Accounting System Design and Evaluation System Based on Internal Control. Communication of Finance and Accounting, 1.

Di, Na. (2010). Study on Internal Financial Control Evaluation Methods in Colleges and Universities. Master Thesis of Yanshan University.

Gong, Jufang. (2005). Careful Implementation of "Accounting System for Business Enterprises" and "Agricultural Enterprises Accounting Method" and Comprehensive Improvement of Financial Management Level in Agricultural Enterprises. Chinese Agricultural Accounting, 1.

He, Xuling \& Wang, Dechun. (2004). Problems and Countermeasures Existing in Financial Accounting in Agricultural Enterprises. Chinese Agricultural Accounting, 5.

He, Xuling. (2004). Study on Accounting System Problems in Agricultural Enterprises. Doctorial Dissertation of Shandong Agricultural University.

Li, Ping \& Liu, Zhiqin. (2005). The Latest Agricultural Accounting Operation Standard and Case Study. Economic Science Press, 7. 
Luo, Qiong \& Luo, Guomin. (2007). Comparison of "Biological Assets --- Accounting Standard for Business Enterprises" and "Financial Accounting System for Agricultural Enterprises". Chinese Agricultural Accounting, 3.

Ministry of Finance of the People's Republic of China. (2001). Accounting System for Enterprises in 2001. Economic Science Press, 2.

Ministry of Finance of the People's Republic of China. (2004). Agricultural Enterprises Accounting Method. China Financial and Economic Publishing House.

Ministry of Finance of the People's Republic of China. (2006). Accounting Standards for Business Enterprises. [Online] Available: http://www.mof.gov.cn/

Ministry of Finance of the People's Republic of China. (2008). Relevant Stipulations on Implementation of 'Accounting Standards for Business Enterprises' by Agricultural Enterprises. [Online] Available: http://www.mof.gov.cn/

Qi, Haodong. (2004). Several Questions about Accounting Standards on Our Country's Agriculture. Accounting Research, 6.

Yang, Qiulin. (2002). Discussion on Several Problems in Formulation of Accounting Methods of Agriculture. Chinese Agricultural Accounting, 6.

Table 1. Completeness evaluation system of accounting system in agricultural enterprises

\begin{tabular}{|c|c|c|c|c|c|c|}
\hline \multirow{2}{*}{$\begin{array}{l}\text { Comprehens } \\
\text { ive } \\
\text { evaluation } \\
\text { index }\end{array}$} & \multirow{2}{*}{\multicolumn{2}{|c|}{ Single evaluation index }} & \multicolumn{4}{|c|}{ Evaluation result } \\
\hline & & & \multirow{2}{*}{ Yes } & \multirow{2}{*}{$\begin{array}{l}\text { Almost } \\
\text { yes }\end{array}$} & \multirow{2}{*}{$\begin{array}{l}\text { Not } \\
\text { much } \\
\text { yes }\end{array}$} & \multirow[t]{2}{*}{ No } \\
\hline \multirow{6}{*}{$\begin{array}{l}\text { Accounting } \\
\text { system } \\
\text { U1 }\end{array}$} & $\mathrm{U}_{11}$ & $\begin{array}{l}\text { whether evaluated agricultural enterprises refer to new } \\
\text { accounting norm system to design and use accounting } \\
\text { subject }\end{array}$ & & & & \\
\hline & $\mathrm{U}_{12}$ & $\begin{array}{l}\text { whether the content and requirement of accounting } \\
\text { document, accounting book, accounting report form } \\
\text { and other data comply with regulations of the new } \\
\text { accounting norm system and other rules of accounting }\end{array}$ & & & & \\
\hline & $\mathrm{U}_{13}$ & $\begin{array}{l}\text { whether the accounting method of agricultural } \\
\text { enterprises is in accordance with the specified } \\
\text { accounting processing method }\end{array}$ & & & & \\
\hline & $\mathrm{U}_{14}$ & $\begin{array}{l}\text { whether the accounting system designed by agricultural } \\
\text { enterprises take full consideration of characteristics of } \\
\text { agricultural production activities }\end{array}$ & & & & \\
\hline & $\mathrm{U}_{15}$ & $\begin{array}{l}\text { maneuverability whether the accounting system } \\
\text { designed by agricultural enterprises has flexible } \\
\text { maneuverability }\end{array}$ & & & & \\
\hline & $\mathrm{U}_{16}$ & $\begin{array}{l}\text { whether the content of accounting system designed by } \\
\text { agricultural enterprises is complete, scientific and } \\
\text { rational according to the new accounting norm system } \\
\text { and other accounting rules }\end{array}$ & & & & \\
\hline \multirow{3}{*}{$\begin{array}{l}\text { Accounting } \\
\text { organization } \\
\text { system } \\
\mathrm{U}_{2}\end{array}$} & $\mathrm{U}_{21}$ & $\begin{array}{l}\text { whether evaluated agricultural enterprises set up } \\
\text { accounting department, principals of accounting } \\
\text { department and accounting positions }\end{array}$ & & & & \\
\hline & $\mathrm{U}_{22}$ & $\begin{array}{l}\text { whether evaluated agricultural enterprises allocate } \\
\text { corresponding qualified accountants in accordance with } \\
\text { the obligation requirements of accounting positions }\end{array}$ & & & & \\
\hline & $\mathrm{U}_{23}$ & $\begin{array}{l}\text { whether accountants are employed with certificates, } \\
\text { equipped with necessary professional knowledge and }\end{array}$ & & & & \\
\hline
\end{tabular}




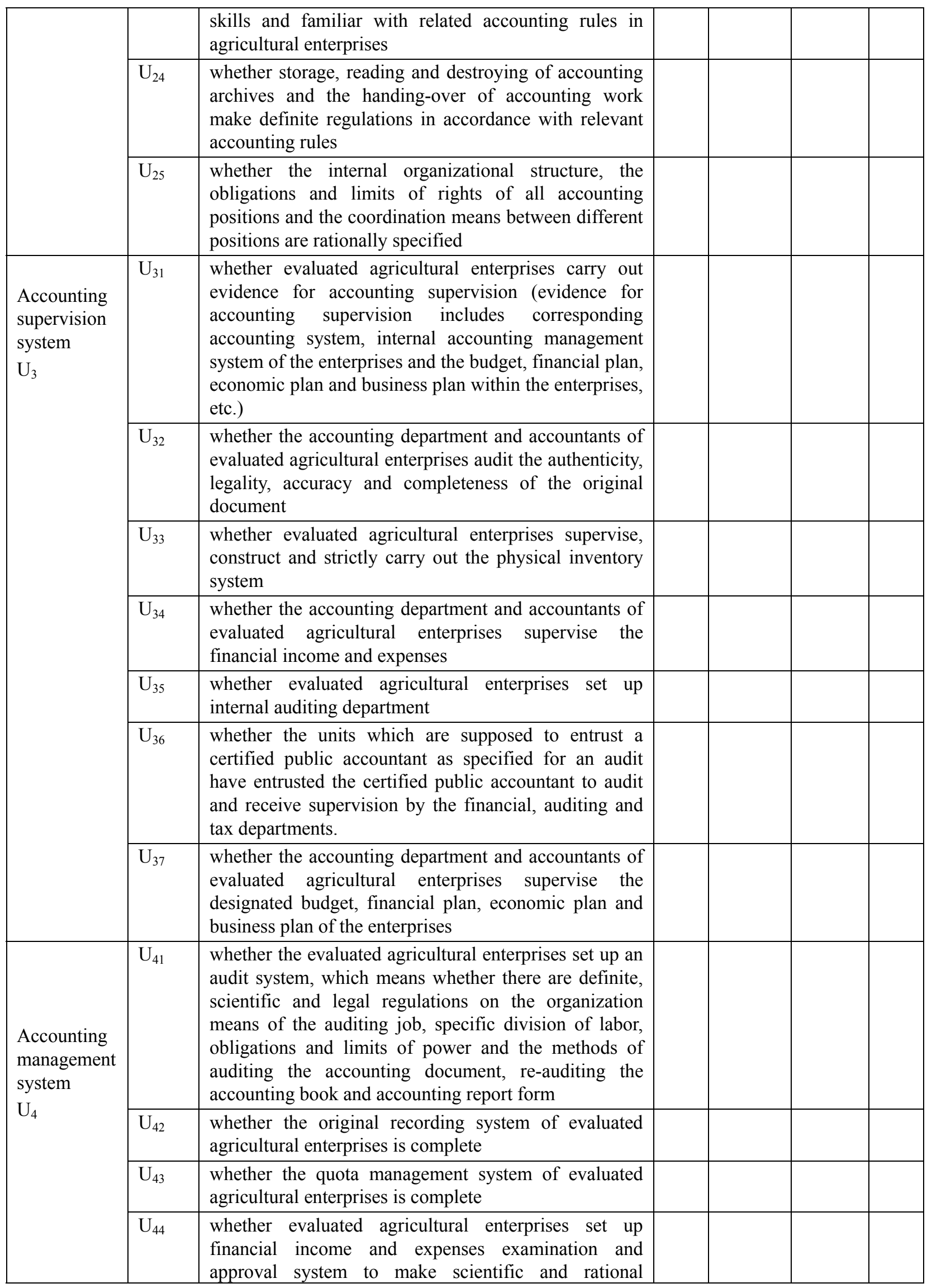




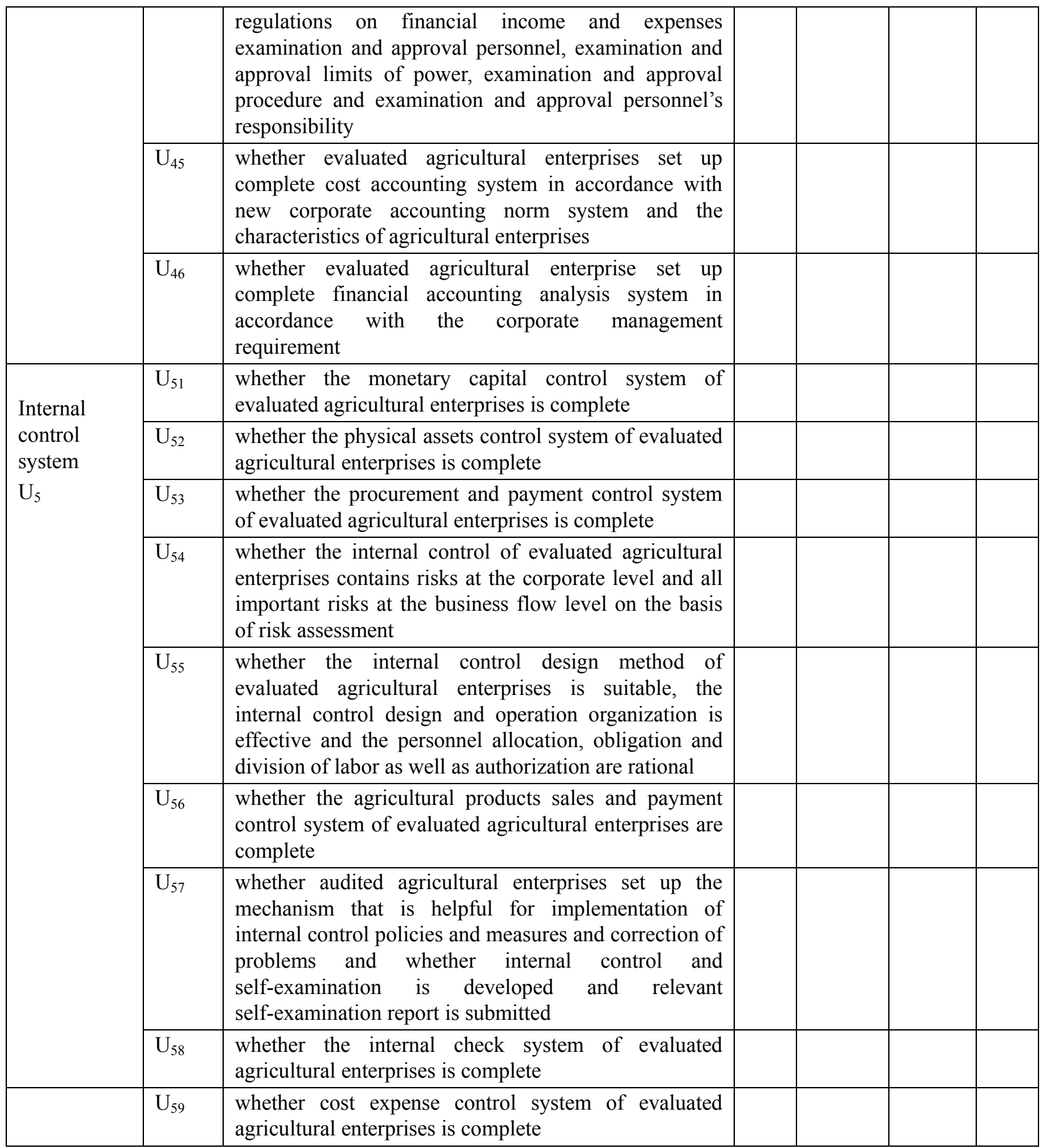

Table 2. Confirmation of the degree of membership

\begin{tabular}{|l|llllc|}
\hline Class & $\mathrm{V}_{1}$ & $\mathrm{~V}_{2}$ & $\cdots$ & $\mathrm{V}_{\mathrm{x}}$ \\
\hline $\begin{array}{l}\text { The number of population that believes a certain } \\
\text { evaluation index u belongs to a certain class }\end{array}$ & $\mathrm{P}_{1}$ & $\mathrm{P}_{2}$ & $\cdots$ & $\mathrm{P}_{\mathrm{x}}$ \\
\hline $\begin{array}{l}\text { Degree of membership of all indexes to different } \\
\text { evaluation classes }\end{array}$ & $\mathrm{P}_{1} / \mathrm{P} \mathrm{P}_{2} / \mathrm{P}$ & $\cdots$ & & $\mathrm{P}_{\mathrm{x}} / \mathrm{P}$ \\
\hline
\end{tabular}

Note: $\mathrm{p}$ is the effective questionnaire survey number, $\mathrm{P}=\mathrm{P}_{1}+\mathrm{P}_{2}+\ldots+\mathrm{P}_{\mathrm{x}}$ 